\title{
\begin{tabular}{l|l|l}
\hline Journal of Innovation, Evaluation and Learning Development \\
\hline
\end{tabular}
}

\section{Peran Orang tua dalam Membimbing Anak Usia Sekolah Dasar di Rumah pada Masa Pandemi Covid-19}

\author{
Enung Nurhasanah \\ Program studi Pendidikan Bahasa Inggris, STKIP Yapis Dompu \\ E-mail: enungnazwa@gmail.com
}

Article History: Received: 2021-08-19 || Revised: 2021-08-20 || Published: 2021-08-20

Sejarah Artikel : Diterima: 2021-08-19 || Direvisi: 2021-08-20 || Dipublikasi: 2021-08-20

\begin{abstract}
The problem raised in this study is how the role of parents in guiding elementary school-aged children at home during the Covid-19 pandemic in Kareke Village, Dompu District, Dompu Regency, This research uses qualitative research with a phenomenological approach. Collecting data in the field using observation, interview, and documentation techniques. The subjects of this study consisted of two parents who have children aged 6-12 years, 6 families, 7 children and also a teacher who lives in the hamlet of Raba Desa Kareke, Dompu District, Dompu Regency. Subject determination used purposive sampling, data analysis was used descriptively. The results of this study indicate that the role of parents in guiding primary school-aged children at home during the Covid-19 pandemic in Kareke Village, Dompu District, Dompu Regency has been implemented even though it is not optimal like in school. All because many of the children's parents are busy with their work and also the lack of understanding of parents towards children's learning materials. But parents still have a sense of caring about children's education. On average, both high school and postgraduate graduates provide guidance at night by learning according to the parents' abilities. Parents usually guide and motivate children in different ways. Sometimes there are those who give the lure of gifts, give praise, advice or there are those who give punishment, so that children want to learn while at home.
\end{abstract}

Keywords: The role of parent, guiding children, Pandemic, Covid-19.

\begin{abstract}
Abstrak
Permasalahan yang diangkat dalam penelitian ini adalah bagaimana peran orang tua dalam membimbing anak usia sekolah dasar di rumah pada masa pandemi covid-19 di Desa Kareke Kecamatan Dompu Kabupaten Dompu. Penelitian ini mengunakan penelitian kualitatif dengan pendekatan fenomenologi, Pengumpulan data di lapangan mengunakan teknik observasi, wawancara,dan dokumentasi.Yang menjadi subjek penelitian ini terdiri dari kedua orang tua yang memiliki anak usia 6-12 tahun sebanyak 6 keluarga ,anak berjumlah 7 orang dan juga seorang guru yang bertempat tinggal di dusun Raba Desa Kareke Kecamatan Dompu Kabupaten Dompu, penentuan subjek mengunakan purposive sampling, Analisis data digunakan secara deskriptif.Hasil penelitian ini menunjukan bahwa Peran orang tua dalam membimbing anak usia sekolah dasar di rumah pada masa pandemi covid-19 di Desa Kareke Kecamatan Dompu Kabupaten Dompu adalah telah dilaksanakan walau kurang maksimal seperti di sekolah.Semua dikarenakan banyak dari orang tua anak yang sibuk dengan pekerjaanya dan juga kurangnya pemahaman orangtua terhadap materi pembelajaran anak.Tetapi orang tua tetap memiliki rasa peduli pada pendidikan anak, rata-rata baik dari narasumber yang lulusan SMA atau pasca sarjana, melakukan bimbingan di malam hari dengan pembelajaran sesuai kemampuan orangtua, orang tua biasa membimbing maupun memotivasi anak dengan cara berbeda-beda. Terkadang ada yang memberi iming-iming hadiah, memberikan pujian, nasehat maupun ada yang memberikan hukuman, agar anak mau belajar selama berada di rumah.
\end{abstract}

Kata kunci: Peran Orang tua, Bimbingan, Anak, Pandemi, Covid-19.

\section{PENDAHULUAN}

Saat ini Dunia tenggah di hebohkan oleh sebuah musibah yang sangat besar, yaitu adanya virus atau wabah yang menyerang manusia di seluruh dunia yaitu dikenal dengan Corona Virus Disease (Covid-19), dimana virus atau wabah ini menyerang siapapun, Pada tanggal 30 Januari 2020 World Health Organisation (WHO) telah menetapkan sebagai kedaruratan kesehatan masyarakat yang meresahkan dunia, Tanggal 2 Maret 2020 Presiden Republik Indonesia mengumumkan kasus pertama Covid-19 di Indonesia dan menghimbau masyarakat untuk mengurangi segala bentuk 
aktivitas di luar rumah demi menekan penyebaran Covid-19 di Indonesia, pemerintah mengeluarkan beberapa kebijakan untuk menghentikan laju penyebaran Covid-19. Salah satunya mengalihkan pembelajaran di sekolah menjadi pembelajaran di rumah masing-masing, Hasil wawancara awal peneliti dengan ibu "N" pada tanggal 16 September 2020, yang bertempat tinggal di Dusun Raba Desa Kareke mengatakan bahwa:

“Orang tua merasa tugasnya semakin banyak karena harus bekerja sekaligus mengajarkan anakanaknya, sehingga orang tua merasa kelimpungan menggurus anak-anaknya dan berharap agar virus corona segera ada obatnya sehingga anak-anak dapat belajar di sekolah seperti biasanya" $(W / N / 16 / 9 / 2020)$.

Peran orang tua juga sangat diperlukan utuk memberikan edukasi kepada anak-anaknya yang masih belum bisa memahami tentang pandemi yang sedang mewabah, untuk tetap berdiam diri di rumah agar tidak tertular dan menularkan wabah pandemi ini, Orang tua memiliki berbagai macam peran terhadap anak-anaknya baik berperan sebagai ibu yang mengurus rumah tangga,ayah sebagai pencari nafkah tetapi keduanya juga memiliki peran peduli terhadap pendidikan anak itu sendiri seperti menjadi fasilitator, pembimbing, motivator dan lain sebagainya, Dalam situasi seperti ini Peran orang tua memiliki kedudukan yang penting dalam membimbing maupun memotivasi anak-anaknya, baik orang tua yang berpendidikan tinggi atau rendah bahkan tidak berpendidikan sekalipun, sama-sama memiliki peran yang sama dalam hal pendidikan anak. Berdasarkan pengamatan awal penulis di Dusun Raba Desa Kareke Kecamatan Dompu Kabupaten Dompu, anak usia sekolah (7-12 tahun) masih ada sebagian yang hanya memanfaatkan waktu belajar di rumah dengan bermain tanpa memikirkan belajar.Itu dikarenakan kurangnya pengawasan serta bimbingan orang tua, karena kesibukan orang tua dalam pekerjaan maupun mengurus keperluan rumah.Bahkan banyak pula yang bekerja di ladang dan sawah, sehingga menyebabkan anak acuh tak acuh pada pendidikannya, dan lebih memilih bermain dan orang tua tidak fokus mengajarkan anak, Tetapi masih ada juga kesadaran orang tua dalam membimbing anak-anaknya belajar, mengarahkan serta menasehati terkait dengan corona dan proses belajar yang harus dilakukan saat masa seperti sekarang, agar anaknya tetap belajar walau itu bukan di sekolah, melainkan belajar bersama orang tua di rumah. Berdasarkan wawancara awal peneliti dengan seorang guru yang mengajar disalah satu sekolah di Desa Kareke mengatakan:

"Penyakit corona bukan sebuah penyakit ringan sehingga sekolah memutuskan menutup kegiatan belajar mengajar yang dilakukan sekolah dan melakukan pembelajaran di rumah, dengan guru wali kelas untuk siswa di kelas tinggi memberikan tugas melalui aplikasi whatsapp untuk dikerjakan siswa, Tetapi tidak bertahan lama dan kembali pembelajaran dilakukan di rumah oleh orang tua".

Dalam keadaan seperti sekarang sekolah mengalami dilema.Antara tetap mengajarkan siswa di sekolah atau diliburkan sampai keadaan semakin kondusif dan pihak sekolahpun pernah membuka lagi akses belajar mengajar pada awal Agustus, setelah menutup sekolah dipertengahan Maret, tetapi dengan kegiatan tidak seefektif sebelum adanya corona dan pihak sekolah mengirimkan surat untuk orang tua terkait ijin para murid tentang memulai lagi kegiatan pembelajaran di sekolah dengan cara belajar mengajar disesuaikan dengan protokol kesehatan, tetapi pada tanggal 18 september 2020 dengan pemberitaan resmi bahwa kondisi corona di daerah Dompu semakin banyak yang tertular dan menyebar dengan cepat, pihak sekolah pun menutup kembali akses pembelajaran di sekolah sampai waktu yang belum ditentukan, Oleh karena itu berdasarkan permasalahan diatas penulis merasa tertarik untuk meneliti lebih dalam"Peran Orang Tua Dalam Membimbing Anak Di Rumah Pada Masa Pandemi Covid-19 Di Desa Kareke Kecamatan Dompu Kabupaten Dompu".

\section{METODE PENELITIAN}

Penelitian ini adalah penelitian yang bersifat kualitatif dengan pendekatan fenomenologi yang berusaha menggali, memahami, dan mencari fenomena sosial yang kemudian menghasilkan data yang mendalam. Pendekatan fenomenologi berhubungan dengan pemahaman tentang kehidupan keseharian dan dunia intersubjektif (dunia kehidupan) partisipan, penelitian fenomenologi mencoba menjelaskan atau mengungkap makna konsep atau fenomena pengalaman yang didasari oleh kesadaran yang terjadi pada beberapa individu, Menurut Alase (2017) fenomenologi adalah sebuah metodologi kualitatif yang mengizinkan peneliti menerapkan dan mengaplikasikan 
kemampuan yang menyatakan bahwa penelitian kualitatif adalah sebuah penelitian yang tertarik untuk menganalisis dan mendeskripsikan pengalaman sebuah fenomena individu dalam dunia sehari-hari. Dengan menggunakan pendekatan fenomenologi penelitian ini bertujuan untuk mengetahui dan memahami peran orang tua dalam membimbing anak usia sekolah dasar di rumah pada masa pandemi COVID-19 di Desa Kareke Kecamatan Dompu Kabupaten Dompu.

Penelitian ini dilakukan di Dusun Raba, RT 13 dan 14, RW 07, Desa Kareke, kecamatan Dompu, Kabupaten Dompu. Lokasi tersebut di ambil dengan mengunakan prosedur Kuota yaitu seberapa banyak orang yang di pakai sebagai narasumber. kemudian narasumbernya harus masuk keteria mengetahui dengan permasalahan atau memiliki wawasan dalam topik penelitian (Burhan Bugis,2007:108). yaitu dalam hal ini kriteria yang di maksudkan adalah orang tua yang memiliki anak usia sekolah dasar yang pasti bertempat tinggal di Dusun Raba.Karna keterbatasan waktu dan lain sebagainya sehingga peneliti haya mengambil 6 keluarga di jadikan narasumber sebagai orang tua anak, 7 anak serta 1 guru sebagai pelengkap data yang di gunakan, Sumber data dalam penelitian adalah subjek dari data yang diperoleh. Adapun sumber yang Penulis gunakan dalam menyusun skripsi ini dikelompokkan menjadi dua yakni sumber primer dan sumber sekunder.Berdasarkan kutipan diatas, maka sumber data primer dalam penelitian ini yaitu orang tua yang memiliki anak usia 6-12 tahun, anak itu sendiri dan guru yang tinggal di Dusun Raba Desa Kareke Kecamatan Dompu Kabupaten Dompu, sumber data sekunder dalam penelitian ini adalah dokumen-dokumen terkait Desa tempat penelitian baik profil desa,kisi misi desa, jumlah penduduk yang memiliki anak usia sekolah dasar di Dusun Raba Desa Kareke, serta berupa buku, jurnal, artikel, skripsi yang berkaitan tentang peran orang tua dalam membimbing anak usia Sekolah Dasar di rumah pada masa pandemic.

Teknik pengumpulan data.Untuk mengetahui peran orang tua dalam membimbing anak usia sekolah dasar di rumah pada masa pandemi COVID-19 maka penulis menggunakan metode sebagai berikut: metode observasi, metode wawancara ,metode dokumentasi, Teknik analisis yang digunakan dalam penelitian ini adalah teknik analisis data kualitatif, Analisis kualitatif dilaksanakan dengan tujuan agar peneliti mendapatkan makna data untuk menjawab masalah penelitian, oleh karena itu, dalam analisis kualitatif data-data yang terkumpul perlu disistematisasikan, distrukturkan, agar memiliki makna yang utuh, pada saat wawancara, peneliti sudah analisis jawaban yang diwawancarai, bila kurang memuaskan setelah jawaban dianalisis, maka peneliti akan melanjutkan pertanyaan lagi sampai tahap tertentu, model ini menganalisis secara terus menerus sampai tuntas, sehingga datanya sudah jenuh, sehingga peneliti benar-benar mendapat hasil yang sesuai dengan fakta lapangan tanpa adanya rekayasa, aktivitas dalam analisis data yaitu di awali dengan pengumpulan data (Data Collection), selanjutnya mereduksi data (Data Reduction), penyajian data (data display), dan kesimpulan (Conclusion Drawing/Verification).

\section{HASIL DAN PEMBAHASAN}

Gambaran Umum Lokasi Penelitian. Desa Kareke adalah merupakan desa yang berada di wilayah Kecamatan Dompu Kabupaten Dompu NTB, Desa Kareke merupakan desa yang terbentuk sejak tahun 2002 yang merupakan pecahan dari Desa Lepadi yang saat itu sebagai desa induk dengan luas wilayah Desa Kareke seluas 16,38 ,KM², Desa kareke pertama kali dipimpin oleh Ibrahim H.Abdullah melalui pemilihan secara demokrasi pada tahun 2002 sampai tahun 2007, selanjutnya pada tahun 2007 sampai 2012 dipimpin oleh Drs. Mustakim H Yakub. kemudian tahun 2013 sampai tahun 2019 dipimpin oleh Ibrahim H Abdulah dan sekarang di pimpin oleh M. Arsyad A.Salam, S.Sos.

Tabel 1. Identitas Subjek Penelitian

\begin{tabular}{ccccc}
\hline No & Inisial Subjek & Usia Subjek & Pendidikan Subjek & Jumlah Anak \\
\hline 1 & SA/SR & $33 / 32$ & S1/S1 & 2 \\
\hline 2 & JN/JN & $30 / 28$ & S1/SMA & 2 \\
\hline 3 & MR/NI & $45 / 42$ & SMA/SMA & 4 \\
\hline 4 & SN/RI & $45 / 42$ & SMA/SMA & 3 \\
\hline 5 & MK/SI & $36 / 39$ & S1/S1 & 1 \\
\hline 6 & AN/SI & $42 / 38$ & SMA/SMA & 2 \\
\hline
\end{tabular}


Tabel 2. Anak Usia 7 Sampai 12 Tahun Duduk di bangku Sekolah Dasar pada Keluarga subyek penelitian

\begin{tabular}{|c|l|c|c|c|c|c|}
\hline No & $\begin{array}{l}\text { Inisial } \\
\text { anak }\end{array}$ & $\begin{array}{c}\text { Inisial } \\
\text { Orang tua }\end{array}$ & Usia & Kelas & RT & Jenis Kelamin \\
\hline 1 & AM & SA/SR & 8 Tahun & 2 SD & 14 & P \\
\hline 2 & UR & JN/JN & 12 \& 7 Tahun & 6 dan 1 SD & 14 & P dan L \\
\hline 3 & RS & MR/NI & 9 Tahun & 3 SD & 14 & L \\
\hline 4 & PR & SN/RI & 9 Tahun & 3 SD & 13 & P \\
\hline 5 & AZ & MK/SI & 8 tahun & 2 SD & 13 & L \\
\hline 6 & PA & AN/SI & 11 tahun & 5 SD & 13 & P \\
\hline
\end{tabular}

Pada suatu keluarga orang tua khususnya memiliki peran sangat penting dalam membimbing anak belajar terutama dalam keadaan seperti sekarang yang sekolah-sekolah masih di tutup demi memutus mata rantai penyebaran virus corona, sehingga orang tua dituntut untuk bisa selalu membimbing dan memotifasi anak selama belajar di rumah, dengan keadaan seperti sekarang orang tua harus bisa membimbing serta memotivasi anak untuk terus belajar walau tidak sepenuhnya seperti pembelajaran di sekolah, setidaknya anak tetap belajar dengan bimbingan serta motivasi dari orang tuanya di rumah, Maka dapat dipaparkan hasil penelitian sebagai berikut:

a) Keluarga SA/SR

Berdasarkan hasil observasi yang peneliti lakukan pada keluarga SA/SR bahwa ibu SR sedang mengajar anaknya di malam hari setelah solat magrib disertai anak pertamanya yang juga masih SMP sedang memangang buku masing-masing untuk belajar, anak pertamanya belajar sendiri sedangkan anaknya yang masih kelas dua diajarkan membaca, Begitupun berdasarkan wawancara yang penulis dapatkan dari keluarga SA/SR yang memiliki pekerjaan sebagai guru honorer mengenai membimbing anak selama di rumah mengatakan bahwa:

"Kami memberikan bimbingan kepada anak tidak dilakukan setiap harinya, dikarenakan kesibukan kami bekerja, di tambah saya yang kini hamil besar menyebabkan waktu untuk mengajar kurang, Namun demikian, kami tetap mengajarkan anak jika ada waktu yaitu disaat malam hari,dengan terus memberikan nasehat dan kadang memberikan hadiah sebagai motivasi untuk anak dapat belajar." (W/N1/10/10/2020)

Data yang diperoleh dari subjek penelitian tersebut dapat didukung oleh pernyataan informan (anak) SA/SR yang mengatakan bahwa:

"Ibu dan ayah memberikan bimbingan pada malam hari, setelah solat magrib. Walau belajarnya tidak setiap hari tetapi Ibu dan ayah tetap mengajarkan saya membaca dan menulis".

b) Keluarga JN/JN

Berdasarkan hasil observasi peneliti pada keluarga JN/JN pada malam hari. JN sedang mengajarkan anaknya belajar membaca, sedangkan ibunya berinisial JN pula sedang mengurus dagangan dan anak pertama pun sedang mengerjakan tugas yang diberikan gurunya, Adapun hasil wawancara yang penulis dapatkan dari keluarga JN/JN yang bekerja sebagai serabutan dan pedagang, mengenai membimbing anak selama di rumah mengatakan bahwa:

"Kami sebagai orangtua tidak lupa untuk mengawasi mereka belajar. Untuk anak pertama kami yang kini kelas 5 SD, dia bisa mengerjakan tugas yang diberikan guru. tetapi jika ada yang anak kurang paham, maka akan menanyakan pada kami sebagai orag tua.Namun karena kadang-kadang kami juga tidak selamanya mengerti dengan tugas anak kami yang diberikan gurunya, maka kamipun menayakan pada paman dari anak-anak yang berprofesi sebagai guru juga, untuk anak kami yang kelas 1 SD, kami mengajarinya membaca di malam hari walau tidak setiap hari, biasanya setelah solat magrib. Karena siang hari anak-anak susah untuk diajak belajar akibat bermain.ketika ingin memulai mengajari anak maka kami memotivasinya dengan cara memberikan cerita lucu sebelum belajar" (W/N2/10/10/2020).

Data yang diperoleh dari subjek penelitian tersebut dapat didukung oleh pernyatan informan (anak) JN/JN yang mengatakan bahwa:

"Bapak dan mamah tetap mengajarkan kami dan belajarnya biasa dilakukan setelah magrib tetapi kadang mamah kurang mengerti dengan pelajaran saya begitupun bapak.Sehingga bapak meminta tolong pada paman untuk membantu saya menyelesaikan tugas yang diberi 
guru.Jikalau mamah dan bapak mengerti dengan tugas saya, merekapun membantu saya menyelesaikan tugas tersebut".

c) Keluarga MR/NI

Dari hasil observasi peneliti pada keluarga MR/NI pada malam hari dimana orang tua dari Rabil sedang duduk mendampinggi anak belajar yang diajari oleh kakanya dari rabil dengan kata lain orang tua anak tidak memberi bimbingan secara langsung melainkan melalui anaknya yang lebih besar, berdasarkan wawancara yang penulis dapatkan dari keluarga MR/NI yang bekerja sebagai tukang batu dan ibu rumah tangga, mengenai membimbing anak selama di rumah mengatakan bahwa:

"Saya dan suami tidak mengajarkan anak. tetapi anak kami lebih diajarkan oleh kakaknya yang kebetulan anak kami yang kedua bercita-cita menjadi seorang guru. Sehingga anak lebih bersemangat dalam mengajari adiknya dan belajar pun dilakukan setelah solat isya, Karena waktu setelah isya lebih panjang. Tetapi kami tidak pernah lupa mengawasi dan menasehati untuk belajar dengan rajin serta mendengarkan dan mendampingi saat kakanya mengajarinya" (W/N3/10/10/2020)

Data yang diperoleh dari subjek penelitian tersebut dapat didukung oleh pernyatan informan (anak) MR/NI yang mengatakan bahwa:

"Mamah dan bapak jarang mengajari saya karena mengurus adek saya jadi kakak yang mengajar saya setiap setelah solat isya".

d) Keluarga SN/RI

Dari hasil observasi yang dilakukan peneliti pada keluarga SN/RI bahwa ibu RI sedang membantu anak mengerjakan tugas yang diberi oleh guru di sekolah sedangkan bapak SN sedang sibuk dengan urusan yang berkaitan dengan desa, berdasarkan wawancara yang penulis dapatkan dari keluarga SN/RI yang bekerja sebagai staf desa dan buruh tani, dalam hal membimbing anak selama di rumah mengatakan bahwa:

"Dalam hal membimbing anak kami sebagai orang tua selalu membimbing anak di rumah karena kebetulan anak kami telah mulai belajar di sekolah selama sebulan ini, sehingga guru selalu memberi tugas yang anak harus kerjakan dan kami selalu setia menbimbing anak untuk belajar terutama jika ada tugas dari guru di sekolah,dan kami mengajarkan anak tidak tentu waktu kadang sore atau malam hari tergantung kesibukan kami dan suasana hati anak untuk belajar. Dalam mengajari anak kami melakukan motivasi dengan cara memberi hadiah pada anak" $^{\prime}$ W/N4/11/10/2020).

Data yang diperoleh dari subjek penelitian tersebut dapat didukung oleh pernyatan informan (anak) SN/RI yang mengatakan bahwa:

"Saya sudah mulai sekolah tetapi mamah tetap megajari saya belajar setiap hari karena guru selalu memberi tugas untuk diisi di rumah".

e) Keluarga MK/SI

Dari hasil observasi peneliti temukan bapak MK sedang sibuk mengurus nanam padi di sawah sedangkan ibu SI sedang sibuk dengan mengurus halaman rumahnya dan anaknya sedang asik bermain, berdasarkan wawancara yang penulis dapatkan dari keluarga MK/SI yang bekerja sebagai guru honorer dan guru PNS, dalam hal membimbing anak selama di rumah mengatakan bahwa:

"Demi mencerdaskan anak kami berusaha semaksimal mungkin dalam membimbing anak untuk selalu belajar. Apa lagi ketika dikabarkan anak harus belajar di rumah tetapi sepintar apapun orang tua. Pembelajaran di sekolah dengan di rumah sangat berbeda. Anak terkadang kurang mau menurut perkataan orang tua dalam mengajarkanya, berbeda dengan di sekolah. Walau demikian, kami berusaha mengajarkan anak agar tidak lupa sama sekali dengan pelajaran di sekolahnya. Sebagai ibu yang ingin anaknya cerdas motivasi yang di berikan yaitu dengan cara di hukum"(W/N5/12/10/2020).

Data yang diperoleh dari subjek penelitian tersebut dapat didukung oleh pernyatan informan (anak) MR/NI yang mengatakan bahwa: 
"Mamah kalau saya tidak mau belajar maka akan di hukum ,sehingga saya sering belajar dengan bapak".

f) Keluarga AN/SI

Dari hasil observasi peneliti anak dari AN/SI sedang belajar dan ibu SI sedang disampingnya mengawasi anaknya belajar sekaligus mengurus anaknya yang masih kecil dan pada siang hari peneliti selalu melihat anak dari AN/SI bermain dengan adiknya dan peneliti juga melihat dikala anak dari AN/SI berangkat menuju rumah gurunya, berdasarkan wawancara yang penulis dapatkan dari keluarga AN/SI yang bekera sebagai tukang batu dan ibu rumah tangga dalam membimbing anak selama di rumah mengatakan bahwa:

"Dalam hal membimbing anak, kami jarang membimbingnya dikarenakan adanya kesibukan lain, ditambah sayapun harus mengurus anak saya yang kecil. Namun demikian saya masih memberikan motivasi dengan nasehat-nasehat untuk anak mau belajar" (W/N6/12/10/2020)

Data yang diperoleh dari subjek penelitian tersebut dapat didukung oleh pernyatan informan (anak) MR/NI yang mengatakan bahwa:

"Mamah biasanya sibuk begitupun bapak.Sehingga jarang bisa mengajari saya, tetapi mamah selalu bilang ke saya untuk tetap belajar. karena sebentar lagi akan masuk SMP. Sehingga kadang disela menjaga adik, saya pun tetap belajar".

Dengan berbagai tangapan orang tua di atas peneliti pun tidak luput mewawancarai salah satu guru yang tinggal di Dusun Raba Desa Kareke terkait pembelajaran yang berlangsung di Dusun Raba Desa Kareke selama masa pandemi. Adapun tangapan dari ibu Fitriani adalah:

"Selama corona ada dan menghebohkan Indonesia termaksud Desa Kareke sehingga pembelajaran tidak pasti. tentang pembelajaran di sekolah kadang buka dan kadang ditutup disesuaikan dengan update kasus corona yang ada sehingga anak-anak belajar di rumah masing-masing dan diajarkan oleh orang tuanya, sampai waktu yang belum bisa ditentukan. Tetapi dua bulan belakangan kira-kira mulai tanggal 2 september, kami sebagai guru berinisiatif tetap mengajarkan anak murid kami tetapi bukan di sekolah melainkan di rumah kami sebagai wali kelas mereka. Tempat belajar pun disesuaikan dengan kelas dan wali kelas masing-masing. Contohnya kelas satu belajar di rumah wali kelas satu begitupun seterusnya, agar anak tetap bisa belajar walau hanya 3 kali dalam seminggu".

Pembahasan Hasil penelitian.Dalam kondisi Covid-19 yang pembelajaran biasa anak terima di sekolah, kini harus beralih dengan pembelajaran di rumah masing-masing.Tentunya dibutuhkan peranan orang tua baik dalam dalam membimbing atau memotivasi anak belajar, semua dikarena keluarga merupakan orang yang sering anak jumpai selama di rumah, orangtua sebagai teladan bagi anak-anaknya tentu berusaha memberikan pendidikan dan juga bimbingan yang mengunakan cara atau metode dalam menyampaikan pengajaran kepada anak.Usaha yang dilakukan orangtua tidak harus selalu berjalan dengan lancar, karena akan ada saja kendala yang dihadapi,baik yang datang dari anak maupun yang datang dari orangtua itu sendiri.Kemudian kendala-kendala itu bukan berarti tidak memiliki solusi atau cara yang dilakukan untuk orangtua terapkan, setiap orangtua pasti memiliki cara masing-masing untuk menyelesaikan permasalahan yang muncul. Solusi yang digunakan oleh orangtua tentunya dengan berbagai macam cara, baik mengunakan trik khusus atau bisa mengunakan hukuman atau sanksi pada anak, dengan tujuan agar anak dapat dibimbing dengan maksimal oleh orang tua, karena setiap orangtua memiliki tanggung jawab terhadap anak-anaknya, ditambah saat Corona hadir di tenggah-tenggah kehidupan masyarakat, semua kegiatan dibatasi terutama dalam kegiatan belajar mengajar di sekolah.

Dari hasil penelitian yang dilakuan penulis dapat diketahui bahwa kendala dalam membimbing anak yang dialami oleh keluarga yang memiliki anak usia 7-12 tahun yang tinggal di Dusun Raba Desa Kareke adalah berasal dari orangtua yaitu kesibukan berbagai pekerjaan orangtua dan ada sebagian dari orang tua sedikit kesulitan dalam membimbing anak dikarenakan kurangnya pengetahuan orang tua tentang materi yang anak pelajari, sehingga semua itu menjadi hal mendasar tidak semua orangtua memberikan bimbingan kepada anak secara maksimal, Selanjutnya, kendala yang berasal dari anak adalah hampir semua anak lebih banyak memilih bermain di siang hari ketimbang belajar. 
Hasil penelitian penulis juga mendapatkan bahwa solusi yang dilakukan orangtua dalam membimbing anak belajar selama di rumah yaitu tetap memberikan bimbingan pada anakanaknya, walau tidak sering dan tidak seefektif yang dilakukan guru di sekolah, orangtua pun rata-rata yang tinggal di Dusun Raba Desa Kareke lebih sering melakukan bimbingan dan memotivasi anak untuk belajar yaitu pada malam hari, Terkait membimbing dan juga memotivasi anak dalam belajar selama berada di rumah, tidak ada yang jauh berbeda, rata-rata baik dari narasumber yang lulusan SMA atau pasca sarjana, melakukan bimbingan di malam hari dengan pembelajaran sesuai kemampuan orangtua dan motivasi yang berbeda-beda setiap orang tuanya, terkadang ada yang memberi iming-iming hadiah, memberikan pujian, nasehat maupun ada yang memberikan hukuman, agar anak mau belajar selama berada di rumah yang diajarkan oleh orangtua anak itu sendiri.

\section{SIMPULAN DAN SARAN}

\section{A. Simpulan}

Berdasarkan pemaparan data yang telah diuraikan oleh peneliti pada bab sebelumnya, maka peneliti dapat menarik kesimpulan sebagai berikut: Peran orang tua dalam membimbing anak usia sekolah dasar di rumah pada masa pandemi covid-19 di Desa Kareke Kecamatan Dompu Kabupaten Dompu adalah telah dilaksanakan walau kurang maksimal dibandingkan belajar di sekolah, Semua dikarenakan banyak dari orang tua anak yang sibuk dengan pekerjaanya dan juga kurangnya pemahaman orangtua terhadap materi pembelajaran anak, tetapi orang tua tetap memiliki rasa peduli pada pendidikan anak, rata-rata baik dari narasumber yang lulusan SMA atau pasca sarjana, melakukan bimbingan di malam hari dengan pembelajaran sesuai kemampuan orangtua, Dimana orangtua biasa membimbing maupun memotivasi anak dengan cara berbeda-beda, Terkadang ada yang memberi iming-iming hadiah, memberikan pujian, nasehat maupun ada yang memberikan hukuman, agar anak mau belajar selama berada di rumah.

\section{B. Saran}

Berdasarkan hasil penelitian yang diuraikan diatas, maka terdapat beberapa saran guna meningkatkan kualitas pembelajaran, Kepada orang tua agar bisa lebih banyak meluangkan waktu dalam membimbing anak, agar anak bisa mendapatkan pembelajaran secara maksimal dan kedua orang tua harus bisa mendisiplinkan anak tentang jam belajarnya, kapan waktu untuk bermain dan juga kapan waktu untuk belajar, agar dalam membimbing anak bisa berjalan sesuai yang diharapkan walau pembelajaranya tidak sama seperti pembelajaran di sekolah.

\section{DAFTAR RUJUKAN}

Astute, Dewi, dkk. (2016). Analisis Peran Orang tua dalam Meningkatkan Hasil Belajar Siswa Kelas X SMK Muhammdiyah Pontianak. Jurnal Pendidikan dan Pembelajaran Khatulistiwa, 2(6).

Aqib Zainal, Amrullah (2017) Ensiklopedia Pendidikan \& Psikologi. Yogjakarta : Penerbit Andi

Burgin, Burhan (2007) Penelitian Kualitatif. jakarta :Prenada Media Group

Diana Sari (2017) "Peran Orang Tua dalam Memotivasi Belajar Siswa." Jurnal bimbingan dan Konseling Indonesia: Teori dan Aplikasi 5 (November 2017).

Hurlock, Elizabeth B. 2005. Perkembangan Anak Jilid I . Jakarta. Penerbit Erlangga

Hulukati, W. (2015). Peran Lingkungan Keluarga terhadap Perkembangan Anak. Jurnal Musawa IAIN PALU, 7(2), 265-282.0

Ihsan, Fuad. 2011. Dasar-Dasar Kependidikan. PT. Rineka Cipta: Jakarta.

“Kementerian Komunikasi Dan Informatika." https: //kominfo.go.id/ content/ detail/25140/bnpb-perpanjangstatus-darurat-covid-19-hingga-29-mei- 2020/0/berita (di akses 10 Agustus, 2020). 
"Kementerian Pendidikan Dan Kebudayaan Republik Indonesia." https://www.kemdikbud.go.id/main/blog/2020/03/mendikbudterbitkan-se-tentang pelaksanaan-pendidikan-dalam-masadarurat-covid19 (02 Agustus, 2020).

Kementerian Pendidikan dan Kebudayaan. 2016. Mendampingi Anak Belajar di Rumah. Jakarta: Kementerian Pendidikan dan Kebudayaan Nurkholis

"Kisah Dari Wuhan, Awal Pandemi Virus Corona Yang Tidak Akan Terlupakan..."https://www.kompas.com/tren/read/2020/04/14/070100165/kisah-dariwuhan-awal-pandemi-virus-corona-yang-tidak-akan- terlupakan (2 Agustus, 2020).

Menteri Pendidikan. (2020). Surat Edaran Nomor 3 Tahun 2020 Tentang Pelaksanaan Pendidikan dalam Masa Darurat CoronaVirus (COVID-19).

Pangestuti, Retno. 2013. Psikologi Perkembangan Anak Pendekatan Karakteristik Peserta Didik. Jogjakarta: Basosbud.

Puspitasari, R. (2020). Hikmah Pandemi Covid-19 Bagi Pendidikan Di Indonesia. Diakses 02 Agustus 2020, dari Institut Agama Islam Negeri Surakarta website:https://iainsurakarta.ac.id/hikmah-pandemi-covid-19-bagi-pendidikan-diindonesia/

Ratna, Ningrum .W. 2018. Pengaruh peranan dan pola asuh orang tua terhadap hasil belajar siswa sekolah dasar negeri (SDN) di kecamatan Bogor Barat. Jurnal pendidikan,17(2), 129-137)

Sardiman, A.M.2012. Interaksi dan Motivasi Belajar mengajar. Jakarta: Rajawali Pers

Sugiyono. (2011). Metode Penelitian Pendidikan. Bandung. Alfabeta

Undang-Undang Sistem Pendidikan Nasional Nomor 20 Tahun 2003 tentang Sistem Pendidikan Nasional. 2003. Jakarta: Gravindo.

Wahyu Adityo Prodjo (2020). Belajar di rumah antara orang tua gagap adaptasi dan anak tak senang. (online) dari amp. kompas.com. website: https://amp.kompas.com/edu/read/2020/05/04/211943371/belajar-dari-rumah-antaraorangtua-gagap-adaptasi-dan-anak-tak-senang. (di akses 18 agustus 2020)

Winingsih, Endang. (2020). Peran orang tua dalam pembelajaran jarak jauh. Agustus, 2020. Poskita.co:https;//poskita.co/2020/08/02/peran-orang-tua-dalampembelajaran-jarakjauh. 